\title{
Research and Development Spillover, Irrigation Water Use and Agricultural Production in Pakistan
}

\author{
MUHAMMAD USMAN ${ }^{1}$, GULNAZ HAMEED ${ }^{2}$, ABDUL SABOOR $^{3}$, LAL KHAN ALMAS*4 \\ ${ }^{1}$ Paul Engler College of Agriculture \& Natural Sciences, WTAMU \\ and Department of Economics, Arid Agriculture University Rawalpindi, \\ PAKISTAN \\ ${ }^{2}$ Department of Economics, Arid Agriculture University Rawalpindi, \\ PAKISTAN \\ ${ }^{3}$ Department of Economics, Arid Agriculture University Rawalpindi, \\ PAKISTAN \\ ${ }^{* 4}$ Agricultural Business and Economics, Paul Engler College of Agriculture \& Natural Sciences \\ West Texas A\&M University, Canyon, Texas, USA
}

Abstract: This research entails investigation of the impacts of Research and Development (R\&D) spillover and irrigation water use efficiency on agricultural productivity in Pakistan. Influenced through the importance of R\&D spillovers in innovation, water scarcity, irrigation technology, internal and external R\&D shocks, human capital, agriculture employment and land were analyzed in the agricultural productivity. Considered the research objectives the annual timeseries data is collected for the period of 1973 to 2020 from different sources. The Autoregressive Distributed Lag (ARDL) model is applied to investigate the contribution of knowledge spillover and water resources efficiency for agricultural production in Pakistan. The results suggest the presence of positive and significant impact of foreign and domestic R\&D spillovers on agriculture productivity of Pakistan. Further, the study found presence of larger positive externalities associated with external R\&D spillovers in agriculture productivity. The estimates highlight that efficient utilization of water technology performs positive role in agriculture productivity in Pakistan. The results of both human capital and interactive term have negative sign and are significant which has clearly indicated that agriculture labor has less absorptive ability of foreign knowledge spillover. From the estimated results, it is recommended that government needs to focus on availability and accessibility of advance technology for farmers through increased outreach and extension services to educate the farmers and accelerate adoption of innovation in agriculture. Further, it is recommended that the Pakistani government must focus on the exploration of alternative irrigation technology in agriculture production for efficient use of water to increase agriculture productivity. Through the adoption of advanced irrigation techniques, the farmers can conserve the irrigated water, enhance water use efficiency in food production and overcome climatic challenges for agriculture production as well as food insecurity issues in Pakistan.

Keywords: Agriculture R\&D, Water Technology, Water Efficiency, Absorptive Ability, Agricultural Productivity, Quantitative Analysis

Received: February 17, 2021. Revised: July 3, 2021. Accepted: July 16, 2021. Published: August 4, 2021. 


\section{Introduction}

The R\&D spillover contributes to the development of agriculture in both direct and indirect ways. Directly, the host countries enhance agricultural output and ensure food security and accessibility, while indirectly R\&D spillovers enhance the farmer's innovative thing, irrigation efficiency, absorptive ability, learning by doing, and helps in emission reduction [1][2][3]. Spillover has positive and negative consequences; due to positive shock, the economy can enhance economic growth and achieve higher output. In contrast, the adverse shock affects economic progress and development. Commonly, the spillover effect reflects third-party benefits or losses. Knowledge spillover in agriculture reflects the reciprocation of ideas among countries, states, or individuals. Knowledge spillover in agriculture is a non-rival that has no cost on the neighbor's farmers to improve their technology, irrigation technique through other's innovation. Such innovations are reflected through specialization in their respective fields. There are several channels through which the technology can diffuse in a host country, containing trade openness, foreign direct investment (FDI) inflow, patent flows, technology imports, advance irrigation techniques and other domestic transmission mechanisms, which are dependent on the country's internal effort for innovation.

Innovation is a primary determinant to attain higher output, production efficiency, profitability, irrigated water efficiency, food security, and competitiveness in the agriculture sector. Globally, evidence shows a science gap in the potential agriculture output to meet food requirements, which is harmful to the competitiveness in the agriculture-food industry [4]. Innovation is not a unanimous process or even uniformly distributed globally. Numerous constraints affect the agriculture innovation system like demographic structure, geographical location, irrigated water and techniques, country land structure, remote areas, weather conditions, farming system, research gap, and country knowledge spillover [5][6]. Additionally, it concludes that the agriculture farm and food industries near to research center have higher innovative performance over firms or farms distant located [7][8]. Agriculture innovation is divided into two broader categories, technological advancement (like new product varieties, net technologies, farming techniques, and farm activities) and non-technological innovation (organizational management, offfarm activities, farmers education, food processing, agriculture marketing, etc.) [4][9]. The non-technical invention also includes a change in behavior and thinking of the farmers, a unique collaboration with farm and off-farm businesses and establishes branding systems [10]. Innovation adoption is a key for $R \& D$ spillovers through developing linkages between agriculture farms, enterprises, and farmers who focused to take initiative and adopt new products, new farming techniques, and new organizational inventions for socio-economic development.

Technological spillover in the agriculture sector provides automation and permits an optimum level of input to reduce the labor demand and monitoring cost of growing crops, judge the quality of land and water, provide digital logistics and trustworthy consumers [9]. In 2017, for the first time in the world, a crop was harvested entirely operated through a technology, the milestone was called "eagriculture" or "smart farming" [9]. Internet, mobile and other devices, artificial intelligence, delivery system, and apps are mainly associated with digital technologies, those are highly valuable and transforming factors. Globally, the agriculture value addition performs a progressive role in equalized distribution of income. The robust results highlighted that agriculture structure, off-farm diversification, innovative technology diffusion, and horticulture facilities are sources for agriculture growth and poverty alleviation in agriculture [11]. In this scenario, the government agriculture investment is an essential tool, which provides the accessibility on R\&D innovation to the agrarians; [8] revealed that public spending on agriculture performs a positive impact on agriculture growth. To attain the benefits from innovative technology spillovers, the farmers require scientific knowledge, skill development programs, and government policy measures. The workable government policy includes promoting the coordination among farmers and agriculture 
extension services, developing a system to educate the farmers, diversification workshops in farm and non-farm activities, etc. [11][12][13].

In Pakistan, the previous research studies focused on technology innovation in the industrial sector through the channels of FDI, there is not significant literature found on technology spillover impact on agriculture productivity. In addition, the R\&D spillover effects on agriculture productivity through the technological transformation and water technology adoption from domestic and foreign sources is missing, further, existing literature not considered the R\&D spillover effect on the agriculture output in Pakistan. Based on existing studies in agriculture sector of Pakistan, the following fundamental questions were not properly addressed. Why the agriculture sector is inefficient? Is it due to the absence of $R \& D$ spillover or absorptive ability? Why did the agriculture sector fail in achieving the desired level of output in Pakistan? Is it because of traditional farming or lack of R\&D and its spillover opportunities? Further, the question concerns whether the farmers are skilled enough to adopt the new technology. If farmers adopted innovation, what probability is that farmers can utilize it for high yield, profitability, and for food security? Why the surface water has low efficiency in Pakistan? What alternative technologies are required to increase the surface water efficiency and irrigated water conservation? Does agriculture labor have absorptive ability to adopt for innovation efficiently? Does domestic R\&D spillover perform potential role in agriculture output or foreign?

The novelty of this research is we includes both internal and external R\&D channels and absorptive capacity to investigate the agriculture productivity in Pakistan. R\&D is driven by innovation spillovers, through which farmers produce the high yield varieties. The $R \& D$ based knowledge spillovers enhance the farmers ability to opt the innovation, efficiency, water conservation technology and farm level productivity. We presented this mechanism in our estimated model to evaluate the $R \& D$ spillovers and knowledge capacity to absorb innovation in agriculture sector of Pakistan. The motivation of this paper is a worldwide increasing role of $\mathrm{R} \& \mathrm{D}$ spillover in agriculture and its importance for productivity and food security in Pakistan, further, the agriculture share to GDP is decreasing in Pakistan. Globally, there is a small gap between actual and potential agriculture output. In Pakistan, there is a tremendous gap between actual and potential agriculture output. Which shows thar Pakistani agriculture sector has potential to gain higher productivity, which can be helpful in upcoming climate and food security challenges. By keeping in view, the importance of $R \& D$ and its spillovers authors has discussed the drivers of innovations in the agriculture sector of Pakistan. This study determines the problems with R\&D spillover, the adoption of technology, agrarians' absorptive ability, and essential concerns for lowering the agriculture share to GDP. Further, this study will find the gap between foreign and domestic R\&D spillover and production inefficiency of the agriculture sector. This research contributes to the literature in such ways, as it focuses on the role of R\&D spillover, water efficiency and farmer's absorptive ability in agriculture output.

A list of studies adopted the time series analysis to investigate the $R \& D$ spillover impacts on firm or industrial output [6][14][15]. Further, most of the existing literature concentrated on the R\&D spillover contribution to economic growth in developed countries. As different questions arise on existing literature, this research aims to examine the impacts of R\&D spillover in the agriculture productivity of Pakistan. This study also investigates the R\&D spillovers contribution in agriculture output through the absorptive ability of agriculture labor. This research measures the surface water efficiency and suggests the alternative water technology to increase the irrigated water efficiency. Additionally, this study assesses empirical estimates of $R \& D$ capital on agriculture output through a comparison of foreign and domestic R\&D spillovers. Based on empirical findings, this study will suggest comprehensive policy suggestions to attain the potential level of agriculture output and ways to improve the role of $R \& D$ spillover in agricultural productivity. 


\section{Literature Review}

R\&D expenditures has fundamental contribution in innovation and knowledge generation, which brings socio-economic developments for the society in long run. R\&D innovation and its spillover shocks convert a country into knowledge-based economy. Innovation is an obligatory element of agriculture productivity, food availability and accessibility, economic development, and welfare-enhancing instrument for both developed and developing countries. Innovation intensity provides the orientation about the degree and nature of agricultural development toward high and efficient future yield [16]. The computation of agriculture innovation is a neoteric task and required extraordinary intention to boost agricultural productivity and irrigated water efficiency for food availability. A list of economists developed models on innovation spillovers impact on economic growth or industrial performance [14][17][18]. While efficient model on the adoption of innovative technology and its diffusion process is developed by Everett Rogers, "diffusion of innovation" is widely accepted [19]. This model has efficiency to measures the role of $R \& D$ adoption in agriculture output. However, this model neglects the climatic uncertainty in agriculture sector which has effective role in agriculture output.

The R\&D inputs heighten the size and frequency of innovation in any economy [20]. Innovation is essential and long-run determinant for the productivity growth of both the manufacturing and agriculture sectors. In agriculture, innovation in new seeds, products, and the supply of organic food items are fundamental factors for growth. Conversely, research performed by agri-research institutions and agri-universities enhanced the stock of knowledge and converted agriculture farming from traditional to knowledge-based farming [21]. The R\&D spillovers from domestic and foreign sources have constructive and significant contribution in total factor productivity (TFP) growth [18], while bilateral technological imports and foreign direct investment are fundamental channels for R\&D spillovers from foreign sources [22]. Moreover, [18][23] argued that the open economies with small resource can attain more benefits from foreign $R \& D$ then domestic R\&D capital. In contrast, [24] demonstrated that gains from foreign knowledge spillover are depreciating due to distance and terms of trade between country boundaries.

Irrigated water is essential to produce global food, this contributes 40 percent to the production of fiber and food items [25], while vulnerable climate and erratic rainfall increase the water scarcity problems. Water scarcities increase pressure on agriculture production, which can resolve through the adoption of innovative water management technologies and efficient water utilization. The adoption of smart irrigation technology will be helpful to overcome water scarcity and climatic challenges. [26] found that the technical efficiency of agrarians varies across the crop and geographical location, even the farmers are working with similar structure and management strategies. Additionally, [25] argued that prudent management is required for irrigated water in the USA with a combination of advance irrigated technology, farmers' adoption of gravity irrigated technique can reduces the 12 percent water consumption at the same production level. [27] concluded that irrigated efficiency is much lower than the technical and management efficiency in Greece crop sector and pulling groundwater can reduce through the adoption of water technology. [28] argued that pulling the underground water is important for cultivation, while efficiency is lacking in water conservation due to a lack of water technology and management skills. Whereas the innovation which enhances the proficiency of using a natural resource, it does not essentially lead to reduce the relevant resource consumption.

The R\&D spillover in industrial and agriculture sectors is higher in developed countries against the developing countries, which is the foremost reason for excessive economic growth. In Singapore, the average growth rate of $R \& D$ capital was 15 percent from the last 15 years [6]. Further, the contract farmers have produced high-quality yield by adopting innovative technology and quality seeds. Through innovation adoption, the contract farmers significantly earn high profitability [29]. The FDI inflow has a significant and negative 
effect on agriculture output in Pakistan [11]. Dissimilarly, [30] investigated the positive association between FDI inflow and agriculture growth in Pakistan. In addition, the indicators like irrigation water, public sector development, water technology, innovative technology, industrial and services sector growth play a positive role in agriculture growth. The FDI inflows benefit can attain through efficient human capital, skilled base training, efficient labor markets, and efficiently adopting and utilizing domestic factors, institutions, and investors.

The R\&D expenditures are fruitful after a while and enhance the agriculture TFP growth. [31] argued that $R \& D$ expenditure and agriculture productivity has a co-integration relationship, and $\mathrm{R} \& \mathrm{D}$ expenditure performs a positive role in agriculture TFP growth. [13] empirically found a positive association between agriculture investment and TFP. In Punjab, $\mathrm{R} \& \mathrm{D}$ spillover in agriculture is underinvestment. The expenditure on agri-extension, rural roads, and irrigations provides a fundamental role in TFP growth. Net export performed a positive impact on agriculture output and the knowledge spillovers [11]. Similarly, [32] found that quality seeds, modern tractors, water availability, tube-wells source, and skilled agriculture labor are likely determinants of agriculture productivity. However, the fertilizers coefficient exhibits an insignificant impact on agriculture output. The fundamental reasons for the immaterial effect of fertilizers are farmer's illiteracy and distant areas with low extension services to guide the farmers about proper and timely fertilizer intakes.

Both the public and private agricultural R\&D investments appear as a substitute, public R\&D investment crowed out the private investment, while in Pakistan this scenario is reverse, and private agriculture investment crowed out the government investment. In Pakistan, the agriculture sector performs a vital contribution in food insecurity, poverty alleviation, and boosting economic growth. However, the agriculture sector faces a productivity gap because of some fundamental issues. Firstly, the innovative technology and adoption of innovation have reduced agriculture productivity. Tractors and other agriculture technology are incredibly low in horsepower and less in quantity [29]. Secondly, no mechanism has been developed to combat soil erosion [33]. Thirdly, the reason for low agri-productivity is farmer's education, lack of management skills, and fewer extension services. Fourthly, the agriculture sector of Pakistan is facing weak government policies, investment, and development expenditure for agriculture productivity [34]. Sixthly, the agriculture irrigated water has less efficiency due to poor management and water technologies.

The agriculture sector in Pakistan faces the gap between actual output and potential output because of public sector negligence and under R\&D investment. [35] highlighted that the agriculture sector share to GDP is declining over time. The agriculture share is high in terms of value addition, exports share, and employment [13], even public investment in agriculture is rapidly declining since 1970 . Along with the deficiency of government policies for the agriculture sector, still agriculture sector plays a pivotal role in the socio-economic development of Pakistan. The agriculture sector is the cornerstone for Pakistan's economy to feed its largest population. The agriculture production technique can improve through the contribution of foreign and domestic R\&D spillovers. A fundamental goal of every government is to achieve sustainable development through poverty alleviation, employment generation, and equalized distribution of income. In this scenario, agriculture development matters a lot, which provides a higher contribution in employment, food availability, foreign exchange earnings, and raw material to the industrial sector. Agriculture income inequality is high in Pakistan because of skewed land ownership [12][36]. The average growth of the agriculture sector is declining over time; the average growth rate during the period of 2009-10 to 2019-20 was 1.98 percent that is lower than the 4 percent growth rate that was during the green revolution period [11][36].

Comprehensive policies are required to resolve the productivity gap in the agriculture sector of Pakistan. The essential measures are crop diversification, innovative technology, biotechnology-based crops, climate change policy implementation, and skilled agriculture 
labor. Further necessary steps are agriculture credit, farmer access to direct marketing, market price mechanism, a mechanism for fertilizer and pesticide prices, and availability. The agriculture sector has a potential and capacity to feed the domestic population as well as production surplus for exports. It can ensure food security as well as contribute towards stimulating manufacturing growth and foreign exchange earnings [34][35]. [33] argued that the agriculture sector heightened the economic growth, which comes from the crop sector that provides food items, price stability, and profitability. [37] found a positive correlation between domestic cottonseed markets and timevariant volatile prices.

\section{Methodology}

The measurement of growth was firstly introduced by [38] by adopting the endogenous growth determinants. Later on, [39] prolonged and refrained from the growth accounting process by introducing the quality of labor and capital, argued that the TFP of any economy is not associated with technological changes, but knowledge capital and labor efficiency is also important. Initially, agricultural economists developed fundamental linkages between R\&D and agriculture growth. The development of production function and the role of $R \& D$ expenditure in TFP growth were estimated by including the $R \& D$ variable utilized by [14] in agriculture studies. Furthermore, [40] emphasized that R\&D is the main factor for the agriculture growth. The new growth theories emphasized on the role of $R \& D$ spillover through drivers of technological progress in TFP growth [17][20][41].

From empirical literature, it is viewed that earlier studies adopted the Cobb Douglas production function (CDPF) for industrial growth through adaptation of local and foreign R\&D spending, human capital, and other control variables. [22] estimated the TFP of the industrial sector by taking the ratio among output $(\mathrm{Y})$ from the industrial sector over capital stock $(\mathrm{K})$ and labor force (L) engage in the industrial sector. In this study, we adopt the modified form of the CDPF to investigate the
R\&D spillover's impact on agriculture output. The functional relationship among output (Y) and inputs capital (K), labor (L), and technological progress can be specified as follows:

$$
Y=F(K, L, T)
$$

The above function is a traditional output function. Where, Y, K, L, T represents output, capital stock, labor force and technological capital respectively, or normally called $R \& D$ capital [14][42]. This paper works on nationallevel data and utilizes the CDPF to analyze the effect of R\&D spillovers on agriculture output. A list of studies adopted the country-based approach to examine the R\&D spillover impact on firm or industrial output [6][14][15].

\subsection{Empirical Model of $R \& D$ Spillovers in Agriculture}

For empirical analysis, this study focused on the Cobb-Douglas-based growth accounting approach. At the first stage in this approach, the authors generalized CDPF function for agriculture productivity. In the second and final step, the authors regress the agriculture output over R\&D spillover indicators and other possible affecting variables. The general form of the CDPF is as following:

$$
Y_{t}=A_{t} K_{t}^{\alpha_{1}} L_{t}^{\alpha_{2}}
$$

In above equation, $\mathrm{Y}$ is output from agriculture sector, $\mathrm{K}$ is agri-capital stock, $\mathrm{L}$ is agricultural workforce, and $\alpha_{1}$ and $\alpha_{2}$ represent the shares of Agri-capital and workforce, respectively. The ' $\mathrm{t}$ ' in subscript represents the time variation in data, whereas ' $A$ ' represents the TFP or normally called knowledge capital. Through addition of agriculture land variable, the modified form of CDPF is as follows:

$$
Y_{t}=T F P_{t} K_{t}^{\alpha_{1}} L_{t}^{\alpha_{2}} M_{t}^{\alpha_{3}}
$$

In equation (2), $\quad Y_{t}$ is production performance of agriculture sector, the $T F P_{t}$ and $M_{t}$ are total factor productivity and agriculture land, and $\alpha_{3}$ is the share of land in agriculture output in Pakistan, respectively. R\&D spillover measures in agriculture sector by using the CDPF, while the output performance of 
agriculture sector is dependent on the TFP labor force, capital stock and agriculture land. [43] highlights the significance of R\&D spillover and its role in agriculture productivity. Both foreign and domestic R\&D spillover factors are essential to increase the agriculture TFP that largely influence through climate factors and knowledge improvement. The TFP growth can expressed as following:

$$
T F P_{t}=A_{t}^{\beta_{1}} R D d_{t}^{\beta_{2}} R D f_{t}^{\beta_{3}} H C_{t}^{\beta_{4}}
$$

The equation (3) indicates the $\mathrm{TFP}_{\mathrm{t}}$ which is dependent on $A_{t}, R D f_{t}, R D d_{t}$, and $H C_{t}$, those representing the knowledge spillover, foreign and domestic R\&D spillovers, and human capital $\left(\mathrm{HC}_{\mathrm{t}}\right)$. Whereas $\beta$ 's are representing the share of agricultural R\&D inputs. Taking the naturel $\log$ of both sides and applying the properties of log, the new equation is as fallowing:

$$
\begin{gathered}
\ln T F P_{t}=\beta_{0}+\beta_{1} \ln A_{t}+\beta_{2} \ln R D f_{t} \\
\beta_{3} \ln R D d_{t}+\beta_{4} \ln H C_{t}
\end{gathered}
$$

The equation (4) is representing the effectiveness of $R \& D$ spillover in agriculture $\mathrm{TFP}_{\mathrm{t}}$ growth. Different studies measured the effectiveness of R\&D spillovers in manufacturing sector and agriculture sector through the $\mathrm{TFP}_{\mathrm{t}}$ growth approach. [22] argued that countries associated with patent protection have high contribution in $T_{F P}$ from $R \& D$ and its spillovers from internal and foreign sources. The R\&D from domestic and foreign sources promotes the spillover effect and uplifts the innovation performance at country and region level [42][43]. By taking the log of equation (2) and adding the intercept and residual term the equation is as following:

$$
\begin{gathered}
\ln Y_{t}=\alpha_{0}+\ln T F P_{t}+\alpha_{1} \ln K_{t}+\alpha_{2} L_{t}+ \\
\alpha_{3} M_{t}+\epsilon_{t}
\end{gathered}
$$

Through the substitution of TFP growth equation into equation (5) and introducing the interactive term to measures the absorptive ability, the new model is as following:

$$
\ln Y_{t}=\alpha_{0}+\alpha_{1} \ln A_{t}+\alpha_{2} \ln L_{t}+\alpha_{3} \ln K_{t}+
$$

$$
\begin{gathered}
\alpha_{4} \ln _{t}+\alpha_{5} \ln R D f_{t}+\alpha_{6} \ln R D d_{t}+ \\
\alpha_{7} \ln H C_{t}+\alpha_{8} \ln R D * H C_{t}+\in_{t}
\end{gathered}
$$

The equation (6) is the final modified form of CDPF to examine the behavior of $R \& D$ spillover and agricultural productivity growth through the channels of absorptive ability in the case of Pakistan.

In equation (6), $Y_{t}$ is a dependent variable representing the agriculture output. The independent variables are $A_{t}$, which is a technological innovation in agriculture sector; $L_{t}$ is labor working in the agriculture sector; $K_{t}$ is capital stock; $M_{t}$ is representing the agriculture land in Pakistan; $R D f_{t}$ is $\mathrm{R} \& \mathrm{D}$ from foreign sources which measures through technology imports, trade openness and FDI $\mathrm{t}_{\mathrm{t}}$ inflow; $R D d_{t}$ is $\mathrm{R} \& \mathrm{D}$ from domestic innovation which measured through technological innovation research in the agriculture sector, new seedling; $H C_{t}$ is human capital, $R D * H C_{t}$ is interactive term of $\mathrm{R} \& \mathrm{D}$ with $\mathrm{HC}_{\mathrm{t}}$ is utilized to capture the role of absorptive ability; and $\epsilon_{t}$ is representing the statistical error term.

The modified estimated model for the analysis of R\&D spillovers competency in agriculture of Pakistan is as follows:

$$
\begin{aligned}
\ln A G D P_{t} & =\alpha_{0}+\alpha_{1} \ln A E X P_{t}+\alpha_{2} \ln A L_{t}+ \\
& \alpha_{3} \ln A T_{t}+\alpha_{4} \ln A E M P_{t}+\alpha_{5} \ln W T I_{t}+ \\
& \alpha_{6} \ln F D I_{t}+\alpha_{7} \ln F I_{t}+\alpha_{8} \ln T I_{t}+ \\
& \alpha_{9} \ln T O P_{t}+\alpha_{10} \ln H C_{t}+\alpha_{11} \ln F D I * \\
& \ln H C_{t}+\epsilon_{t}
\end{aligned}
$$

For empirical analysis, the agriculture percentage share to GDP is taken as a dependent variable. While independent variables include domestic and foreign R\&D, labor force employed in agriculture, agriculture land, and human capital. The descriptions of variables are given in table 1 .

Table 1. Explanation of variables

\begin{tabular}{lll}
\hline Variables & Description & Units \\
\hline Ln AGDP $_{\mathbf{t}}$ & $\begin{array}{l}\text { Agriculture shares } \\
\text { to GDP }\end{array}$ & Percentage share \\
Ln AEXP $_{\mathbf{t}}$ & $\begin{array}{l}\text { Agriculture } \\
\text { Development }\end{array}$ & Public \& Private \\
& in Million \\
Ln AEMPenditure $_{\mathbf{t}}$ & Agriculture & Rupees \\
\hline
\end{tabular}




\begin{tabular}{|c|c|c|}
\hline & Employment & Employment \\
\hline $\operatorname{Ln} \mathrm{TWI}_{\mathbf{t}}$ & $\begin{array}{l}\text { Tube Well } \\
\text { Irrigation }\end{array}$ & Million Hectares \\
\hline $\mathrm{Ln} \mathrm{AT}_{\mathbf{t}}$ & Agriculture & Available per \\
\hline $\operatorname{Ln} \mathrm{AL}_{t}$ & Agriculture Land & $\begin{array}{l}\text { Percentage of } \\
\text { Total Land }\end{array}$ \\
\hline $\mathrm{Ln} \mathrm{HC} \mathrm{H}_{\mathrm{t}}$ & Human Capital & Index \\
\hline $\mathrm{Ln} \mathrm{FI}_{\mathrm{t}}$ & Fertilizer Imports & $1000 /$ tones \\
\hline Ln FDI & $\begin{array}{l}\text { Foreign Direct } \\
\text { Investment }\end{array}$ & $\begin{array}{l}\text { Net Inflows (\% } \\
\text { of GDP) }\end{array}$ \\
\hline $\operatorname{Ln} \mathrm{TI}_{\mathbf{t}}$ & Tractor Imports & $\begin{array}{l}\text { No of Tractor } \\
\text { Imports }\end{array}$ \\
\hline $\operatorname{Ln} \mathrm{TOP}_{\mathbf{t}}$ & Trade Openness & $\begin{array}{l}\text { Percentage of } \\
\text { GDP }\end{array}$ \\
\hline $\begin{array}{l}\mathrm{Ln} \\
\mathrm{HC} * \mathrm{FDI}_{\mathbf{t}}\end{array}$ & Interactive Term & $\begin{array}{l}\text { Absorptive } \\
\text { Ability }\end{array}$ \\
\hline
\end{tabular}

\subsection{Irrigated Water Technology and Efficiency}

Efficient irrigated technology allows applying less water for agriculture yield which reduces the groundwater extraction and effective in drought resistant [44][45]. An increase in water efficiency decreases water consumption and technical efficiency is effective in climate vulnerability. The efficiency of irrigated water can be measured through the proportion of consumed water effectively used for crop production. The irrigated water efficiency is defined as a fraction of effective water to consumable water. The consumable water efficiency can calculate through applied water minus return flows from the respective crop, while the effective water is basically, the water that is efficiently/beneficially used for crop production [28]. Mathematically we can express this formula as following,

$$
\begin{aligned}
& \text { Irrigated Water Efficiency } \\
& \qquad=\frac{\text { Effective Water }}{\text { Consumed Water }}
\end{aligned}
$$

This proportion of efficient irrigated technology allows to apply less water for irrigation, which increases the land capacity, soils quality and provides water and nutrients for yield. For example, dropped nozzles irrigation, drip irrigation, bio-saline irrigation, etc. are effective technology for irrigated water conservation. According to [46], drip irrigation saves the pumped irrigated water on average 25 to 75 percent compared to flood irrigation.

\subsection{Data and Data Source}

The aim of this research is to examine the effectiveness of R\&D spillover on agriculture growth in Pakistan. For empirical output, this study collected the annual timeseries data for the period of 1972 to 2020 . The data for empirical analysis is collected from different domestic and international resources. The secondary source data is composed from World Development Indicators (WDI), Panne World Table (9.1 \& 10.0), different economic surveys of Pakistan, Pakistan Agriculture Research Council (PARC), Ministry Food and Agriculture Development, Pakistan Metrology Department, Pakistan Bureau of Statistic (PBS), and Pakistan Ministry of Finance. For quantitative analysis E-views 9 a computer package is used.

\section{Results and Discussion}

\subsection{The Stationarity Test Results}

The purpose of this research is to explore the effects of R\&D spillover and water efficiency on agriculture growth in Pakistan. To avoid the spurious analysis, firstly, the unit root test is applied to investigate the deterministic trend of all concerned variables. The stationary behavior of the series executes to find the suitable analysis technique to assess the long-term relationship. The time-series data is strongly influenced through its previous value, and if variables are non-stationary in regression analysis it violates the standard assumption of asymptotic analysis. To avoid the superior's regression and find the deterministic trend, the Augmented Dickey-Fuller (ADF) unit root test is applied on all series individually. The results of the ADF test are given in table 2. The ADF test results suggested that six variables are stationarity at the first difference I(1) together with the dependent variable, and five variables are stationarity at level $\mathrm{I}(0)$. The ADF test results highlighted a mix-stationary pattern and 
suggested that the ARDL model is appropriate for long-run analysis. period is nine months; otherwise, most of crop yields come within six months.
Table 2. Results of ADF Test

\begin{tabular}{|c|c|c|c|}
\hline Variables & Level & $\begin{array}{l}\text { First } \\
\text { Difference }\end{array}$ & $\begin{array}{l}\text { Integratio } \\
\mathrm{n} \text { order }\end{array}$ \\
\hline $\mathrm{LAGDP}_{\mathbf{t}}$ & $\begin{array}{l}-1.9408 \\
(0.3112)\end{array}$ & $\begin{array}{l}-3.6807 \\
(0.0078)^{*}\end{array}$ & $\mathrm{I}(1)$ \\
\hline $\mathrm{LAEXP}_{\mathbf{t}}$ & $\begin{array}{l}-3.7762 \\
(0.0272)^{*}\end{array}$ & $\begin{array}{l}-5.2459 \\
(0.0005)\end{array}$ & $\mathrm{I}(0)$ \\
\hline $\mathrm{LAEMP}_{\mathbf{t}}$ & $\begin{array}{l}-1.1515 \\
(0.6874)\end{array}$ & $\begin{array}{l}-8.2817 \\
(0.0000)^{*}\end{array}$ & $\mathrm{I}(1)$ \\
\hline $\mathrm{LTWI}_{\mathbf{t}}$ & $\begin{array}{l}-1.6185 \\
(0.4654)\end{array}$ & $\begin{array}{l}-7.5722 \\
(0.0000)^{*}\end{array}$ & $\mathrm{I}(1)$ \\
\hline $\mathrm{LAT}_{\mathbf{t}}$ & $\begin{array}{l}0.1234 \\
(0.9643)\end{array}$ & $\begin{array}{l}-8.0061 \\
(0.0000) *\end{array}$ & $\mathrm{I}(1)$ \\
\hline $\mathrm{LAL}_{\mathbf{t}}$ & $\begin{array}{l}-4.8676 \\
(0.0017)^{*}\end{array}$ & $\begin{array}{l}-5.2142 \\
(0.0007)\end{array}$ & $\mathrm{I}(0)$ \\
\hline $\mathrm{LHC}_{\mathrm{t}}$ & $\begin{array}{l}-1.6703 \\
(0.4393)\end{array}$ & $\begin{array}{l}-6.6419 \\
(0.0000)^{*}\end{array}$ & $\mathrm{I}(1)$ \\
\hline $\mathrm{LFI}_{t}$ & $\begin{array}{l}-4.1350 \\
(0.0108)^{*}\end{array}$ & $\begin{array}{l}-7.0716 \\
(0.0000)\end{array}$ & $\mathrm{I}(0)$ \\
\hline $\mathrm{LFDI}_{t}$ & $\begin{array}{l}-3.0918 \\
(0.0342)^{*}\end{array}$ & $\begin{array}{l}-4.6607 \\
(0.0004)\end{array}$ & $\mathrm{I}(0)$ \\
\hline $\mathrm{LTI}_{\mathbf{t}}$ & $\begin{array}{l}-1.7105 \\
(0.4195)\end{array}$ & $\begin{array}{l}-7.1796 \\
(0.0000)^{*}\end{array}$ & $\mathrm{I}(1)$ \\
\hline $\mathrm{LTOP}_{\mathbf{t}}$ & $\begin{array}{l}-5.0230 \\
(0.0009)^{*}\end{array}$ & $\begin{array}{l}-7.7964 \\
(0.0000)\end{array}$ & $\mathrm{I}(0)$ \\
\hline
\end{tabular}

\subsection{Lag Length Selection}

After investigating the stationery, the unrestricted VAR model is utilized for the selection of optimum lag, which is important for timeseries analysis to figure out the effect of previous periods on current values. The appropriate lag selection is helpful to avoid the bias analysis and autocorrelation. Consequently, the suitable lag is chosen based on Akaike Information Criterion (AIC), which provides robust results over Hannan-Quinn Criterion (HQC) and Schwarz-Bayes Criterion (SBC). The results highlighted lag 2 is optimal lag and suitable for given sample size, also reflect the nature of agriculture productivity (See table 3 ). In addition, the maximum agriculture production
Table 3. Lag Selection Criterions

\begin{tabular}{cccc}
\hline Lag & AIC & SC & HQ \\
1 & 70.4718 & $75.3783^{*}$ & 72.2914 \\
2 & $66.0543^{*}$ & 75.8674 & $69.6935^{*}$ \\
3 & 53.6631 & 68.3827 & 59.1218 \\
4 & -463.100 & -443.4743 & -455.822 \\
\hline
\end{tabular}

\subsection{ARDL Bound Test}

For quantitative analysis, the ARDL cointegration technique is applied. The ARDL bound test is applied to check the existence of a cointegration relationship [47]. The estimates of the bound test are given in table 4. The calculated value of the F-statistic (6.34) is larger than the upper bound critical value. The results of the bound test validate the rejection of the null hypothesis of "no long-run relationship" and confirm the presence of a long-term association among R\&D spillovers and $\mathrm{AGDP}_{t}$ in Pakistan. The estimates are consistent with the results of [48][49] who argued that the FDI inflow and technology imports have a long-run association with agriculture productivity.

Table 4. ARDL Bound Test Results

\begin{tabular}{lcc}
\hline F-statistic & \multicolumn{2}{c}{6.34194} \\
\hline \multicolumn{3}{c}{ Critical Bounds value } \\
Sig. & Lower-Bound & Upper-Bound \\
$5 \%$ & 2.45 & 3.61 \\
$1 \%$ & 3.15 & 4.43 \\
\hline
\end{tabular}

\subsection{Long-Run ARDL Coefficients}

The estimates of the long-run analysis are shown in Table 5. In the estimated model, the dependent variable is agriculture share to GDP $\left(\mathrm{AGDP}_{\mathrm{t}}\right)$, while independent variables are $\mathrm{R} \& \mathrm{D}$ domestic and foreign. To capture the R\&D domestics, the authors use the agriculture development expenditure $\left(\mathrm{AEXP}_{\mathrm{t}}\right)$, Agriculture Tractors per 100 square $\mathrm{km}\left(\mathrm{AT}_{\mathrm{t}}\right)$, and Tube Well Irrigation per 1000 hector $\left(\mathrm{TWI}_{\mathrm{t}}\right)$. To measure the foreign R\&D spillover, the authors took the Foreign Direct investment inflow 
$\left(\mathrm{FDI}_{\mathrm{t}}\right)$, Trade openness $\left(\mathrm{TOP}_{\mathrm{t}}\right)$, Tractor Imports $\left(\mathrm{TI}_{\mathrm{t}}\right)$, and Fertilizers Imports $\left(\mathrm{FI}_{\mathrm{t}}\right)$ as key indicators. The other control variables are human capital index $\left(\mathrm{HC}_{\mathrm{t}}\right)$, Agriculture Employment share in total employment $\left(\mathrm{AEMP}_{\mathrm{t}}\right)$, and Agriculture land as a percentage of total land $\left(\mathrm{AL}_{\mathrm{t}}\right)$ are taken as independent variables.

The estimated results show that foreign R\&D has a significantly positive impact on agriculture productivity while domestic R\&D indicators shows mixed effect on agriculture share to GDP. The estimated coefficient of $\mathrm{AEXP}_{t}$ has a significantly positive impact on agriculture productivity with a coefficient value of 0.0426. This specifies that a one percent increase in agriculture development expenditure (either private or public) leads to increase the AGDP $_{t}$ by 4 percent. The estimated results are similar with the outcomes of [8][13], argued that the $R \& D$ expenditure on agri-extension, rural roads, fertilizers and pesticides, new seeds, advanced technology adoption, and irrigations provide a fundamental role in agriculture output. The estimated coefficient of $\mathrm{AEMP}_{t}$ has a negative and insignificant impact on agriculture productivity. The reason for the insignificant impact of $\mathrm{AEMP}_{t}$ is the inefficiency of agriculture labor, Agri-labor is not well educated, skilled, trained and uptodate with agriculture inventions which is incredibly important in adopt the innovation. Further, the agriculture sector of Pakistan is over-employed, which is reason for insignificant impact of agriculture labor in agriculture production. Economic theory suggests that the additional input utilization after certain limit effects the agriculture output negatively.

The estimated coefficient of tube well irrigation $\left(\mathrm{TWI}_{\mathrm{t}}\right)$ shows a positive and significant influence on agriculture $\mathrm{AGDP}_{\mathrm{t}}$. The significant value of $\mathrm{TWI}_{t}$ coefficient shows that as the tube-well irrigation increases by one percent the agriculture GDP will increase by 8 percent annually. The water pulling through tube-well performs productive role in agriculture output, while the surface irrigate of tube-well water has less efficiency and depletion of energy and water. The pulling of underground water may cause the level of under-groundwater and become the reason of climate vulnerability. The findings are consistent with [50] who concluded that tube-well irrigation is not a foremost constraint for irrigation and water buyers have inefficiency over tube-well owners in productivity. [28] argued that pulling the underground water is important for cultivation but efficiency is lacking in water usage due to lack of water technology and management skills. In addition, [51] highlights that irrigation management and technologies are fundamental constraints, including advanced technology availability, institutional support, and socioeconomic condition for agriculture production.

The estimated coefficient of available agriculture technology $\left(\mathrm{AT}_{\mathrm{t}}\right)$ has a significantly negative impact on agriculture GDP of Pakistan. The reason behind this negative impact is that technology available for agriculture production is not sufficient and even obsolete technology with low horsepower is utilized for cultivation, which causes lower agriculture productivity. The estimates are similar with the findings of [29][51] who highlights that irrigation management is a key constraint including advanced technology availability, institutional support, and socio-economic condition for agriculture production. In addition, [4] found that the modest innovation in agriculture produced gap between actual and potential output. The adoption of technological innovation is the initial step to enhancing productivity, but the affordability of new technology is a key issue for the majority of the farmer's, especially for small-scale farmers [52]. Further, the farm with efficient agriculture labor and innovative technology reduces the losses of planting and harvesting of agriculture yield.

The results of Agriculture Land $\left(\mathrm{AL}_{\mathrm{t}}\right)$ have a significantly positive impact on agriculture output. As more land is devoted for agriculture purposes, with other efficient input factors of production, the agriculture productivity will increase in long-term. The estimated value of $\mathrm{AL}_{t}$ is significant at one percent with the elasticity of 0.30 , which shows that a percent rise in agri-land leads to rise the $\mathrm{AGDP}_{t}$ by 30 percent. This indicates that agricultural land holds a 30 percent share in agriculture productivity. The findings highlight that one percent increase in agriculture land share in total land contains high share in agriculture output 
production. The land ownership policies playing a key role in the agriculture sector and land inputs made a remarkable contribution to agriculture output [52].

The results of Human Capital $\left(\mathrm{HC}_{\mathrm{t}}\right)$ are significantly negative, which indicates that agriculture sector labor force is less educated due to which the farmers are unable to get potential level of output. The results of $\mathrm{HC}_{t}$ reflecting that agriculture knowledge capital is less productivity. The estimated results are alike with the findings of [4][52], who concluded that the farmer's technology adoption reflects through $\mathrm{HC}_{t}$ efficiency and has fundamental contribution in agriculture productivity. The human capital efficiency may enhance through education, better extension services, skilled based training workshops and networking among farmers by highlighting the benefits of innovation adoption. In addition, [32] highlighted that the skilled and educated agriculture labor are suitable determinants of agriculture output.

We measure role of foreign $R \& D$ spillover through four different proxies, such as FDI inflow $\left(\mathrm{FDI}_{\mathrm{t}}\right)$, fertilizer imports $\left(\mathrm{FI}_{\mathrm{t}}\right)$, Tractors Imports $\left(\mathrm{TI}_{\mathrm{t}}\right)$ and trade openness $\left(\mathrm{TOP}_{\mathrm{t}}\right)$. The analysis results of external $\mathrm{R} \& \mathrm{D}$ indicators have significantly positive impact on agriculture GDP. The coefficient elasticities of $\mathrm{FI}_{\mathrm{t}}, \mathrm{FDI}_{\mathrm{t}}, \mathrm{TI}_{\mathrm{t}}$ and $\mathrm{TOP}_{\mathrm{t}}$ are 2.9, 7.9, 2.8 and 10.7 percent, respectively. Further, the $\mathrm{FDI}_{t}, \mathrm{TI}_{\mathrm{t}}, \mathrm{FI}_{\mathrm{t}}$ and $\mathrm{TOP}_{\mathrm{t}}$ benefits can attain through efficient human capital, skilled and efficient labor, and early adoption of foreign R\&D innovation, for this the domestic factors, institutions development and extension policies are important tools. The technology spillover from foreign sources has important contribution in agriculture GDP. The adoption of technological innovation is the initial step to enhance the productivity, however, the affordability of new technology is a key issue for most of the farmers, especially for small scale farmers [52]. The outcomes are consistent with the findings of [30][49] who investigated the positive association among FDI inflow and agriculture growth in Pakistan. [4][6][31] argued that R\&D spending on foreign technology has positive effect on agriculture output. In addition, [11] argued that imports and exports have a significantly positive impact on agriculture productivity. In contrast, [32] found that the usages of fertilizers have an insignificant impact on agriculture output, and that farmers' illiteracy and their distant areas prevent them in gaining optimum fertilizers benefits.

Through interactive term of human capital $\left(\mathrm{HC}_{\mathrm{t}}\right)$ with $\mathrm{FDI}_{\mathrm{t}}$, the authors capture the absorptive ability of agriculture labor. The efficiency of knowledge spillover is dependent on the absorptive ability of the host country and knowledge-based labor can utilize the foreign R\&D efficiently [22]. The interactive term $(\mathrm{HC} * \mathrm{FDI})_{\mathrm{t}}$ shows negative and significant result indicates that the agriculture labor force has less absorptive ability. Agriculture labor is not knowledgeable in opting the foreign technology efficiently. The interactive term results concluded that either the educated labor is not in available, or agriculture knowledge capital is not efficient enough to absorb foreign innovation. The results are consistent with the outcomes of [13][53] who found that the human capital, experience, and training has insignificant impact on agriculture productivity. The human capital investment is required to increase the labor efficiency to attain higher yield.

Table 5. Long Run estimates

\begin{tabular}{lll}
\hline Variable & Coefficient & Prob. \\
\hline LAEXP $_{\mathbf{t}}$ & 0.0426 & $(0.0000)^{* * *}$ \\
LAEMP $_{\mathbf{t}}$ & -0.0896 & $(0.2311)$ \\
LTWI $_{\mathbf{t}}$ & 0.0802 & $(0.0000)^{* * *}$ \\
LAT $_{\mathbf{t}}$ & -0.1358 & $(0.0002)^{* * *}$ \\
LAL $_{\mathbf{t}}$ & 0.3082 & $(0.0001)^{* * *}$ \\
LHC $_{\mathbf{t}}$ & -0.0699 & $(0.0000)^{* * *}$ \\
LFI $_{\mathbf{t}}$ & 0.0297 & $(0.0487)^{* *}$ \\
LFDI $_{\mathbf{t}}$ & 0.0790 & $(0.0284)^{* *}$ \\
LTI $_{\mathbf{t}}$ & 0.0283 & $(0.0041)^{* * *}$ \\
LTOP $_{\mathbf{t}}$ & 0.1074 & $(0.0000)^{* * *}$ \\
LHC $^{*}$ LFDI $_{\mathbf{t}}$ & -0.0524 & $(0.0005)^{* * *}$ \\
Constant & -0.7437 & $(0.1342)$ \\
The $_{*}^{* * *}, * * *$ & represent level of significance \\
at 10, 5 and 1 percent, respectively. \\
\hline
\end{tabular}

\subsection{Short Run Estimates of ARDL Model}

The estimates of short-term coefficients are given in Table 6. The estimated value of lag of AGDP $_{t}$ is positive and insignificant which indicates that previous year agriculture output has no effect on current output. The agriculture 
output is always independent from previous time because the current output has not longer relationship with previous output in case of Pakistan. The reason behind is two cropping seasons (Rabi and Kharif crops) in Pakistan. The $\mathrm{AEXP}_{t}$ in the current period has a positive and significant effect on $\mathrm{AGDP}_{\mathrm{t}}$ in short run, the coefficient value is 0.068 which shows that a one percent increase in $\mathrm{AEXP}_{t}$ enhances the agriculture GDP by 6 percent. The estimated results are similar with findings of [8][31] who argued that expenditure on the R\&D activities perform a positive role in agriculture growth. The AEMP $_{t}$ coefficient has negatively significant effect on agriculture production of Pakistan. The coefficient value is -0.31 which shows that the agriculture sector is over employed with less educated labor, due to which $\mathrm{AEMP}_{\mathrm{t}}$ has negative impact on $\mathrm{AGDP}_{\mathrm{t}}$. The lag coefficient of $\mathrm{AEMP}_{\mathrm{t}}$ is insignificant, which means the previous year's agriculture employment does not affect the current production.

The tube-well land irrigation has positive impact on agriculture productivity. The coefficient value of $\mathrm{TWI}_{t}$ is 0.1416 and significant at one percent. The elasticity values of TWI $\mathrm{T}_{t}$ shows that one percent increase in $\mathrm{TWI}_{t}$ land enhance the agriculture GDP by 14 percent. Interesting results of lag coefficient of $\mathrm{TWI}_{t}$ were found, the negative and significant value of lag coefficient of agriculture land shows that previously irrigated land through tube-well has less productivity in current period. The reason is tube-well irrigation effects the soil fertility which reduces the output in next period. Further, [28] argued that pulling the underground water is important for cultivation but efficiency is lacking in water usage, due to lack of water technology and management skills. In Pakistan, the underground water contains the residual, like sodium carbonate, which is not healthily for soil fertility. The estimates are similar with the results of [50][51]. The coefficient of $\mathrm{AT}_{t}$ has positive and significant effect on agriculture output in both current and lag period. The shortrun $\mathrm{AT}_{t}$ results shows positive and significant impact while in long run $\mathrm{AT}_{t}$ has negative significant impact on $\mathrm{AGDP}_{\mathrm{t}}$. The estimated coefficients are inconsistent with the outcomes of [29][52] while consistent with the findings of
[32] highlighted that modern tractor performs positive role in agriculture productivity.

The estimated coefficient of agriculture land $\left(\mathrm{AL}_{\mathrm{t}}\right)$ has positive but an insignificant impact on $\mathrm{AGDP}_{\mathrm{t}}$ in the short run. The estimated value of lag coefficient of $\mathrm{AL}_{t}$ is significantly negative. The land, which is cultivated in previous period has less fertility, which require 'fellow period' to enhance the fertility. The coefficient value of $\mathrm{HC}_{t}$ has negative and insignificant impact on agriculture production in short period. The lag coefficient of $\mathrm{HC}_{t}$ is positive, which indicates that experienced $\mathrm{HC}_{t}$ has positive effects on agriculture output. The estimated value of fertilizer imports $\left(\mathrm{FI}_{\mathrm{t}}\right)$ has significantly negative on agriculture output in short period because the delay in distribution of imported fertilizers farmers cause lower productivity. The coefficient values of $\mathrm{FDI}_{t}$, lag of $\mathrm{FDI}_{t}, \mathrm{TI}_{\mathrm{t}}, \mathrm{TOP}_{\mathrm{t}}$ and Lag of $\mathrm{TOP}_{\mathrm{t}}$ are positive and significant which shows that foreign $R \& D$ spillover has positive impact in both short and long run. The estimated value of $\mathrm{FDI}_{t}$, lag of $\mathrm{FDI}_{\mathrm{t}}, \mathrm{TI}_{\mathrm{t}}, \mathrm{TOP}_{\mathrm{t}}$ and Lag of TOP $\mathrm{t}$ are similar with the estimates of long-run with small variation in magnitude. The results of interactive term $\left(\mathrm{HC}^{*} \mathrm{FDI}\right)_{\mathrm{t}}$ shows significantly negative impact on agriculture growth, this means the technology imported from external sources is not efficiently absorb. The estimates are alike with the results of [31][53][54] concluded that the technology imported from external sources is not absorbed by domestic farmers.

The estimated model is multivariate time series model, so the error correction model (ECM) is applied for getting the behavior of stochastic trend and adjustment speed of dependent variable towards equilibrium. The coefficient value of $\operatorname{ECM}_{t}(-1)$ is negative and statistically significant, this shows that the estimated model has convergent behavior towards equilibrium. The higher value of ECM $(-1)$ revealed that if there is any disequilibrium in technological inputs, that input shocks can be adjusted with higher speed during the same time period and input variables perform important role to bring agriculture GDP into its steady state position [47]. The $\mathrm{ECM}_{\mathrm{t}}(-1)$ coefficient value is higher due to two crop seasons (Rabi and Kharif) in Pakistan, with uniformly located areas, so if production on one crop is lower, its 
production deficiency will recover either during the same period or during next crop [11][54][55].

Table 6. ARDL Short run/ Cointegrating Form

\begin{tabular}{|c|c|c|}
\hline Variable & Coefficient & Prob. \\
\hline $\mathrm{D}_{\left(\text {LAGDP }_{\mathbf{t}}(-1)\right.}$ & 0.1495 & $(0.2558)$ \\
\hline $\mathrm{D}\left(\right.$ LAEXP $\left._{\mathbf{t}}\right)$ & 0.0681 & $(0.0000) * * *$ \\
\hline $\mathrm{D}\left(\mathrm{LAEMP}_{\mathrm{t}}\right)$ & -0.3107 & $(0.0072) * * *$ \\
\hline $\mathrm{D}\left(\right.$ LAEMP $_{\mathbf{t}}(-1)$ & -0.0717 & $(0.4127)$ \\
\hline $\mathrm{D}\left(\mathrm{LTWI}_{\mathbf{t}}\right)$ & 0.1416 & $(0.0022)^{* * *}$ \\
\hline $\mathrm{D}\left(\operatorname{LTWI}_{\mathrm{t}}(-1)\right)$ & -0.1138 & $(0.0075)^{* * *}$ \\
\hline $\mathrm{D}\left(\mathrm{LAT}_{\mathrm{t}}\right)$ & 0.3218 & $(0.0006) * * *$ \\
\hline $\mathrm{D}\left(\operatorname{LAT}_{\mathrm{t}}(-1)\right)$ & 0.5237 & $(0.0000)^{* * *}$ \\
\hline $\mathrm{D}\left(\mathrm{LAL}_{\mathrm{t}}\right)$ & 0.2571 & $(0.1640)$ \\
\hline $\mathrm{D}\left(\operatorname{LAL}_{\mathbf{t}}(-1)\right)$ & -0.5917 & $(0.0062)^{* * *}$ \\
\hline $\mathrm{D}\left(\mathrm{LHC}_{\mathrm{t}}\right)$ & -1.0263 & $(0.1728)$ \\
\hline $\mathrm{D}\left(\mathrm{LHC}_{\mathrm{t}}(-1)\right)$ & 1.0635 & $(0.0590)^{*}$ \\
\hline $\mathrm{D}\left(\mathrm{LFI}_{\mathbf{t}}\right)$ & -0.0235 & $(0.0637)^{*}$ \\
\hline $\mathrm{D}\left(\mathrm{LFDI}_{\mathrm{t}}\right)$ & 0.0758 & $(0.0321)^{* *}$ \\
\hline $\mathrm{D}\left(\operatorname{LFDI}_{\mathbf{t}}(-1)\right)$ & 0.0271 & $(0.0066) * * *$ \\
\hline $\mathrm{D}\left(\mathrm{LTI}_{\mathbf{t}}\right)$ & 0.0453 & $(0.0027)^{* * *}$ \\
\hline $\mathrm{D}\left(\mathrm{LTOP}_{\mathrm{t}}\right)$ & -0.0830 & $(0.0282)^{* *}$ \\
\hline $\mathrm{D}\left(\operatorname{LTOP}_{\mathbf{t}}(-1)\right)$ & -0.5478 & $(0.0000) * * *$ \\
\hline D(LFDI * & -0.2844 & $(0.0030)^{* * *}$ \\
\hline \multicolumn{3}{|l|}{$\left.\mathrm{LHC}_{\mathrm{t}}\right)$} \\
\hline $\operatorname{ECM}(-1)$ & -1.5972 & $(0.0000)^{* * *}$ \\
\hline \multicolumn{3}{|c|}{$\begin{array}{l}\text { The } *, * *, * * * \text { indicates the significance level } \\
\text { at } 10,5 \text { and } 1 \text { percent, respectively. }\end{array}$} \\
\hline
\end{tabular}

\subsection{Results of Diagnostic Tests}

The results of residual diagnostic and normality estimates are given in Table 7 . The null hypothesis of Jarque Bera (JB) is "data is normally distributed". The JB test value is insignificant and small. This shows that the hypothesis of data normality is not rejected significantly, and data of estimated model is normally distributed. In time series analysis the problem of Heterosckedasticuity and Autocorrelation are quite common that creates the problem of specification bias. The Breusch and Pagan test is applied to test the spread of variance of error term. The calculated value of Breusch-Pagan test is low with insignificant probability value, so the null hypothesis of homosckedasticity is not rejected. The results of Breusch-Pagan show that there is no evidence of Heterosckedasticity in the estimated model. The
Breusch and Godfrey test is adopted to test the problem of autocorrelation in the estimated model. The estimated value of Breusch and Godfrey test is insignificant which show that the null hypothesis of "no Autocorrelation" is not rejected. The results indicate that there is no autocorrelation in estimated residual and selected lags are optimal for dependency relationship.

Table 7. Diagnostic statistics

\begin{tabular}{lll}
\hline Diagnostic Tests & Stat & P-Value \\
\hline Heteroskedasticity Test & 0.5159 & $(0.9338)$ \\
Autocorrelation Test & 1.5518 & $(0.2366)$ \\
Normality Test & 1.4864 & $(0.4755)$ \\
\hline
\end{tabular}

The stability of data is examined through Cumulative Sum (CUSUM) and Cumulative Sum of Square (CUSUMQ) (Figure 1\&2) utilized by [47]. The stability estimates show the existence of long run relation in parameters through short run movements in the estimated model. The CUSUM and CUSUMQ tests are graphical analysis of cointegration equation (called ECM model) which is estimated in ARDL model. The estimated values of CUSUM and CUSUMQ tests lies within 5 percent bounds which is confirmation of the presence of a longterm association among variables and show the stability in estimated coefficients [11][56][57].

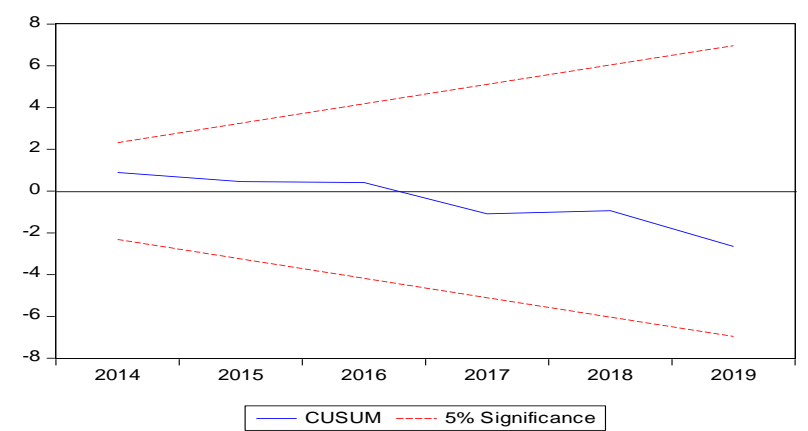

Fig.1: Cumulative Sum. 


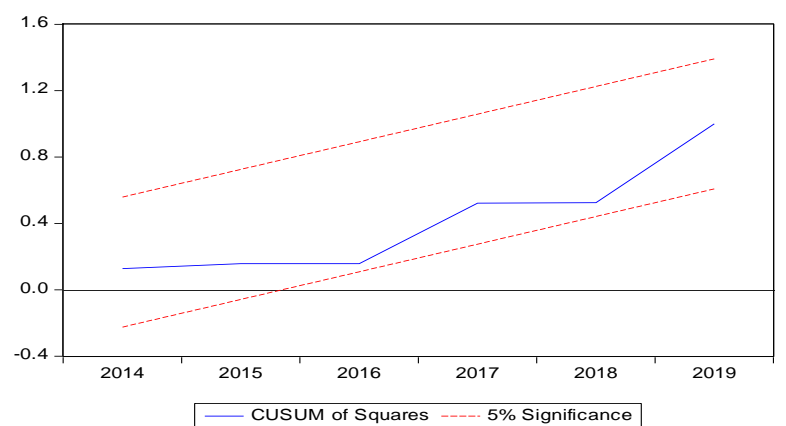

Fig.2: Cumulative Sum of Square

\subsection{Surface Water Efficiency in Pakistan}

The fundamental source of land irrigation in Pakistan is surface water, and about 85 percent of cultivated land is irrigated through surface water [58]. We measured the water efficiency from the ratio of effective water to consumed water. The estimated results indicate that the surface water efficiency in the crop sector ranges between 25 to 40 percent in Pakistan, while the vegetables' surface water efficiency ranges from 30 to 50 percent. Although surface water contribution is low in agriculture production in Pakistan, its efficiency ranges from 25 to 75 percent [58]. The surface water efficiency is extensively low in Pakistan, which required a highly efficient irrigation system and the adoption of innovative irrigated technologies.

In Pakistan, crops grown in both in summer and winter season and list of food (like wheat, rice, corn, sugarcane, etc.) and non-food crops (cotton, sorghum, oilseeds, etc.) are grown. Approximately 95 percent of Pakistan's water is used in agriculture. We measured the water productivity as results are given in figure 3 , the water productivity is increasing over the time from 1972 to 2019. However, the water productivity is increasing with diminishing rate, the forecasted results highlight that in future Pakistan may face the problem of water deficiency, as the forecasted result shows that water productivity will be decreasing return to scale in upcoming decade. The estimates are in line with results of [50]. The reason for decreasing the water productivity is climatic vulnerability, as Pakistan is one the highly climatic vulnerable country in global. The highly efficient government system is required to minimize the water consumption in irrigation to sustain the agriculture productivity.

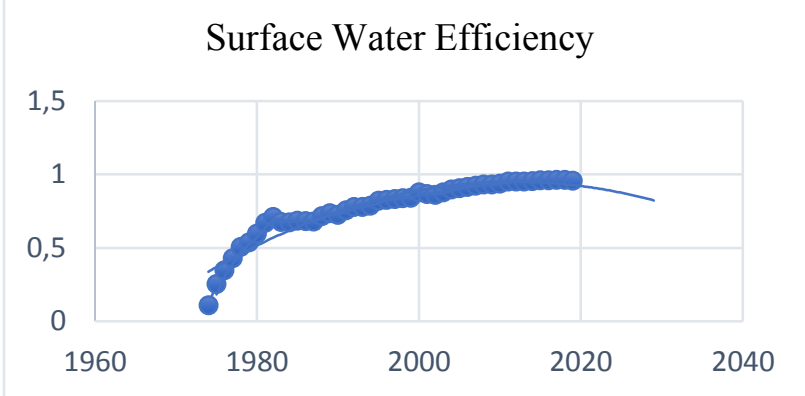

Fig.3: Surface water productivity

\section{Conclusion and Policy Suggestions}

This research examines the impact of $R \& D$ spillover in agriculture productivity in Pakistan. Influenced through the importance of $R \& D$ spillovers in innovation, the impact of domestic and foreign $\mathrm{R} \& \mathrm{D}$, human capital, agriculture employment and land were analyzed in the agriculture productivity. The annual time series data is collected from different sources for the period of 1973 to 2020 . To find the deterministic trend the ADF Stationarity test is applied on all variables individually. The results of ADF test suggested that ARDL model is more suitable because all variables have a mixture of level and first different stationary results. The results of the ARDL-bound test validate the rejection of null hypothesis and confirm the existence of long-run association between R\&D spillover and agriculture productivity in Pakistan. The results indicated that transmission of technology from foreign sources has greater impact in agriculture production over domestic technological innovation. If Pakistan economy is involved in trade, it will get more technological spillover benefits in agriculture. Furthermore, the interactive term indicates that agriculture labor has less absorptive ability of foreign innovation spillovers.

The estimated results show that R\&D foreign has a significantly positive impact on agriculture productivity while domestic $R \& D$ indicators show mix effect on agriculture GDP of Pakistan. The results of agriculture development expenditure show positive impact on AGDP, so the expenditure on agriculture development like new seeds, technology 
adoption, rural roads, access to other input resources and extension services has positive role in agriculture productivity. The negative and insignificant impact of agriculture employment shows that the agriculture sector is over employed and productivity of labor moving diminishing return to scale due to over employment. From analysis it is determined that the investment on tube-well irrigation has positive impact on the current agriculture yield but in lag period it affects the soil fertility and produce negative impact on production. Results show that the availability of tractors is not sufficient in horsepower or obsolete for cultivation, which creates negative impact on agriculture output. The land input produces remarkable contribution in agriculture production in Pakistan. The estimated outcome of FDI inflow, fertilizer imports, tractors imports, and trade openness shows positive impact on agriculture performance. This indicates that $\mathrm{R} \& \mathrm{D}$ spillover from foreign sources has successive contribution in agriculture production and has positive spillover impact on agriculture GDP. The results indicated that both human capital and interactive term (HC*FDI) have significantly negative impact on agriculture GDP. This indicated that labor is less educated, unskilled and not having the ability to adopt innovative technology. So, the investment in human capital enhancement required as much attention as technology spillover required. The negative value of ECM coefficient shows that the estimated model has speed of adjustment towards equilibrium.

The fundamental hurdles for agriculture productivity are because of a lack of policy and policy implementation, lacking research and innovative technology, unskilled agri-labor, innovative seed varieties, water management and managerial skills, climatic policy implementation, and agriculture extension services. On the basis of analysis, it is recommended that additional investment is required to improve the agriculture technology, agriculture human capital and agriculture research activities. The following polices are suggested based on authors analysis:

1. The government should focus on sustainable policies related to domestic R\&D spillover, availability and accessibility of innovation for the farmers.

2. The R\&D spillover can also be generated through independent policies and common agenda with trading countries by reducing the scope of freerider dependency in agriculture sector of Pakistan.

3. Government needed more efforts to develop agriculture research collaboration with stakeholder and provide agriculture research as public good to achieve the potential level output.

4. The government should focus on adoption of imported agricultural technology for improving impact of foreign R\&D spillover.

5. The agriculture extension services required advance policies and implementation for monitoring and educating the farmers about agriculture innovation adoption and environmental factors.

6. Policy is required to improve the extension services and science-based education programs to emphasize on adoption of irrigation technology and better management practices in farming.

7. Public sector is required to focus on water governance at national level, develop appropriate regulations to incentivize the water technology.

8. Agriculture research on plant physiology to develop the water resilient crop varieties which may improve the inputs productivity, water conservation and agro-climatic conditions.

\section{Acknowledgement:}

The research manuscript has been supported though International Research Supports Fellowship Program (IRSFP) by Punjab Higher Education Commission (PHEC), Pakistan, through Mr. Usman's institution, PMAS- Arid Agriculture University, Rawalpindi, Pakistan. Authors also acknowledge the acceptance and support of West Texas A\&M University to host the Visiting Research Scholar from Pakistan. 
References:

[1] Huang, J., Cai, X., Huang, S., Tian, S., \& Lei, H. (2019). Technological factors and total factor productivity in China: Evidence based on a panel threshold model. China Economic Review, 54, 271-285.

[2] Dinar, Z. (2014). Transboundary pollution, R\&D spillovers, absorptive capacity and international trade. International Journal of Economics and Financial Issues, 4(3), 501513.

[3] Jiao, J., Jiang, G., \& Yang, R. (2018). Impact of R\&D technology spillovers on carbon emissions between China's regions. Structural Change and Economic Dynamics, 47, 35-45.

[4] Läpple, D., Renwick, A., Cullinan, J., \& Thorne, F. (2016). What drives innovation in the agricultural sector? A spatial analysis of knowledge spillovers. Land use policy, 56, 238-250.

[5] Hermans, F., Klerkx, L., \& Roep, D. (2015). Structural conditions for collaboration and learning in innovation networks: using an innovation system performance lens to analyse agricultural knowledge systems. The Journal of Agricultural Education and Extension, 21(1), 35-54.

[6] Ho, Y. P., Wong, P. K., \& Toh, M. H. (2009). The impact of $R \& D$ on the Singapore economy: an empirical evaluation. The Singapore Economic Review, 54(01), 1-20.

[7] Breschi, S. (2000). The geography of innovation: A cross-sector analysis. Regional Studies, 34(3), 213-229.

[8] Chandio, A. A., Jiang, Y., Rehman, A., Jingdong, L., \& Dean, D. (2016). Impact of government expenditure on agricultural sector and economic growth in Pakistan. American-Eurasian J. Agric. \& Environ. Sci, 16(8), 1441-1448.

[9] OECD, 2020. New technologies and digitalization are transforming agriculture and offering new opportunities to improve policy.

https://www.oecd.org/agriculture/events/oe cd-global-forum-on-agriculture

[10] Knickel, K., Brunori, G., Rand, S., \& Proost, J. (2009). Towards a better conceptual framework for innovation processes in agriculture and rural development: from linear models to systemic approaches. Journal of Agricultural Education and Extension, 15(2), 131-146.

[11] Ali, I., Khan, I., Ali, H., Baz, K., Zhang, Q., Khan, A., \& Huo, X. (2020). The impact of agriculture trade and exchange rate on economic growth of Pakistan: an NARDL and asymmetric analysis approach. Ciência Rural, 50(4).

[12] Qasim, M., Pervaiz, Z., \& Chaudhary, A. R. (2020). Do Poverty and Income Inequality Mediate the Association Between Agricultural Land Inequality and Human Development?. Social Indicators Research, 151, 115-134.

[13] Nadeem, N., Mushtaq, K., \& Dawson, P. J. (2013). Impact of Public Sector Investment on TFP in Agriculture in Punjab, Pakistan. Pakistan Journal of Social Sciences (PJSS), 33(1) 137-147.

[14] Griliches, Z. (1992). The search for R\&D spillovers. The Scandinavian Journal of Economics, S29-S47.

[15] Nadiri, M. I. (1993). Innovations and technological spillovers. NBER working paper, (w4423).

[16] Ariza, C., Rugeles, L., Saavedra, D., \& Guaitero, B. (2013). Measuring innovation in agricultural firms: A methodological approach.

[17] Grossman, G. M., \& Helpman, E. (1991). Innovation and growth in the global economy. MIT press.

[18] Coe, D. T., \& Helpman, E. (1995). International r\&d spillovers. European economic review, 39(5), 859-887.

[19] Ugochukwu, A. I., \& Phillips, P. W. (2018). Technology adoption by agricultural producers: A review of the literature. From agriscience to agribusiness, 361-377.

[20] Aghion, P., \& Howitt, P. (1990). A model of growth through creative destruction (No. w3223).

[21] Voutsinas, I., \& Tsamadias, C. (2014). Does research and development capital affect total factor productivity? Evidence from Greece. Economics of Innovation and New Technology, 23(7), 631-651.

[22] Coe, D. T., Helpman, E., \& Hoffmaister, A. 
W. (2009). International R\&D spillovers and institutions. European Economic Review, 53(7), 723-741.

[23] Khan, M., Luintel, K. B., \& Theodoridis, K. (2011). How robust is the $R \& D$ productivity relationship? Evidence from OECD countries (Vol. 1). WIPO.

[24] Keller, W. (2010). International trade, foreign direct investment, and technology spillovers. In Handbook of the Economics of Innovation Vol. 2, pp. 793-829.

[25] Mpanga, I. K., \& Idowu, O. J. (2021). A decade of irrigation water use trends in Southwest USA: The role of irrigation technology, best management practices, and outreach education programs. Agricultural Water Management, 243, 106438.

[26] Laureti, T., Benedetti, I., \& Branca, G. (2021). Water use efficiency and public goods conservation: A spatial stochastic frontier model applied to irrigation in Southern Italy. Socio-Economic Planning Sciences, 73, 1008-1056.

[27] Karagiannis, G., Tzouvelekas, V., \& Xepapadeas, A. (2003). Measuring irrigation water efficiency with a stochastic production frontier. Environmental and resource economics, 26(1), 57-72.

[28] Sears, L., Caparelli, J., Lee, C., Pan, D., Strandberg, G., Vuu, L., \& Lin Lawell, C. Y. C. (2018). Jevons' paradox and efficient irrigation technology. Sustainability, 10(5), 15-90.

[29] Khan, M. F., Nakano, Y., \& Kurosaki, T. (2019). Impact of contract farming on land productivity and income of maize and potato growers in Pakistan. Food Policy, 85, 28-39.

[30] Ahmed, A., Devadason, E. S., \& Jan, D. (2017). Does inward foreign direct investment affect agriculture growth? Some empirical evidence from Pakistan. International Journal of Agricultural Resources, Governance and Ecology, 13(1), 60-76.

[31] Khan, F., Salim, R., Bloch, H., \& Islam, N. (2017). The public R\&D and productivity growth in Australia's broadacre agriculture: is there a link?. Australian Journal of Agricultural and Resource
Economics, 61(2), 285-303.

[32] Raza, J., \& Siddiqui, W. (2014). Determinants of Agricultural Output in Pakistan: A Johansen co-integration approach. Academic Research International, 5(4), 30.

[33] Anwer, M., Farooqi, S., \& Qureshi, Y. (2015). Agriculture sector performance: An analysis through the role of agriculture sector share in GDP. Journal of Agricultural Economics, Extension and Rural Development, 3(3), 270-275.

[34] Kasi N., and Mahmood Z. (2016) 'Horizontal and Vertical Spillover Effects of Foreign Direct Investment on Sectoral Productivity in Selected SAARC Countries, School of Social Sciences and Humanities (S3H), NUST.

[35] Ullah, A., Arshad, M., Kächele, H., Khan, A., Mahmood, N., \& Müller, K. (2020). Information asymmetry, input markets, adoption of innovations and agricultural land use in Khyber Pakhtunkhwa, Pakistan. Land Use Policy, 90, 104261.

[36] GoP (2019). Government of Pakistan, Ministary of Finance 2019, http://www.finance.gov.pk/budget_wing.ht $\mathrm{ml}$

[37] Sehar, S., Ling, M., Hassan, S., \& Han, J. (2018). Price Volatility Spillover in Domestic Cotton Markets of Pakistan: An Application Of Dec-Mgarch Model. JAPS, Journal of Animal and Plant Sciences, 28(4), 1152-1162.

[38] Solow, R. M. (1957). Technical change and the aggregate production function. The review of Economics and Statistics, 39(3), 312-320.

[39] Jorgenson, D. W., \& Griliches, Z. (1967). The explanation of productivity change. The review of economic studies, 34(3), 249-283.

[40] Griliches, Z., (1973) Research expenditures and growth accounting." In Science and technology in economic growth. Palgrave Macmillan, London. pp. 59-95

[41] Romer, P. M. (1990). Endogenous technological change. Journal of political Economy, 98(5, Part 2), S71-S102.

[42] Wang, X., Fang, H., Zhang, F., \& Fang, S. (2018). The spatial analysis of regional 
innovation performance and industryuniversity-research institution collaborative innovation-An empirical study of Chinese provincial data. Sustainability, 10(4), 1243.

[43] Salim, R. A., \& Islam, N. (2010). Exploring the impact of $R \& D$ and climate change on agricultural productivity growth: the case of Western Australia. Australian Journal of Agricultural and Resource Economics, 54(4), 561-582.

[44] Pfeiffer, L., \& Lin, C. Y. C. (2014). Does efficient irrigation technology lead to reduced groundwater extraction? Empirical evidence. Journal of Environmental Economics and Management, 67(2), 189208.

[45] Schuck, E. C., Frasier, W. M., Webb, R. S., Ellingson, L. J., \& Umberger, W. J. (2005). Adoption of more technically efficient irrigation systems as a drought response. Water Resources Development, 21(4), 651-662.

[46] Taylor, R., \& Zilberman, D. (2017). Diffusion of drip irrigation: the case of California. Applied economic perspectives and policy, 39(1), 16-40.

[47] Pesaran, M. H., Shin, Y., \& Smith, R. J. (2001). Bounds testing approaches to the analysis of level relationships. Journal of applied econometrics, 16(3), 289-326.

[48] Ahmad, S., Tariq, M., Hussain, T., Abbas, Q., Elham, H., Haider, I., \& Li, X. (2020). Does Chinese FDI, Climate Change, and $\mathrm{CO} 2$ Emissions Stimulate Agricultural Productivity? An Empirical Evidence from Pakistan. Sustainability, 12(18), 74-85.

[49] Baniasadi, M., \& Jala'ee Esfandabadi, S. A. A. (2017). Analysis the impact of technology spillovers on total factor productivity of agricultural sector in Iran. Journal Of Agricultural Economics and Development, 30(2), 117-126.

[50] Watto, M. A., \& Mugera, A. W. (2014). Measuring Production and Irrigation Efficiencies of Rice Farms: Evidence from the $\mathrm{P}$ unjab $\mathrm{P}$ rovince, $\mathrm{P}$ akistan. Asian Economic Journal, 28(3), 301-322.

[51] Aslam, M. (2016). Agricultural productivity current scenario, constraints and future prospects in Pakistan. Sarhad Journal of
Agriculture, 32(4), 289-303.

[52] Abdullahi, H. S., Mahieddine, F., \& Sheriff, R. E. (2015, July). Technology impact on agricultural productivity: A review of precision agriculture using unmanned aerial vehicles. In International conference on wireless and satellite systems, Springer. pp. 388-400.

[53] Djomo, J. M. N., \& Sikod, F. (2012). The effects of human capital on agricultural productivity and farmer's income in Cameroon. International Business Research, 5(4), 1-34.

[54] Usman, M. ., Hameed, G., Saboor, A. ., \& Saddozai, K. N. (2020). Technological Spillovers, Manufacturing Growth and Transboundary Pollution in Case of Pakistan. Journal of Applied Economics and Business Studies, 4(2), 23-40.

[55] Shita, A., Kumar, N., \& Singh, S., (2019). The Impact of Technology Adoption on Agricultural Productivity in Ethiopia: ARDL Approach. Indian Journal of Economics and Business Indian Journal of Economics \& Business, 19 (1) 255-262

[56] Alimi, R. S. (2014). ARDL bounds testing approach to Cointegration: A reexamination of augmented fisher hypothesis in an open economy. Asian Journal of Economic Modelling, 2(2), 103114.

[57] Koondhar, M. A., Li, H., Wang, H., Bold, S., \& Kong, R. (2020). Looking back over the past two decades on the nexus between air pollution, energy consumption, and agricultural productivity in China: a qualitative analysis based on the ARDL bounds testing model. Environmental Science and Pollution Research, 1-15.

[58] Latif, M., Haider, S. S., \& Rashid, M. U. (2016). Adoption of high efficiency irrigation systems to overcome scarcity of irrigation water in Pakistan. Proc. Pak. Acad. Sci. B Life Environ. Sci, 53(4), 243252.

\section{Contribution of Individual Authors to the Creation of a Scientific Article (Ghostwriting Policy)}

Muhammad Usman: This research manuscript is part of his Ph.D. dissertation, and he generated 
research ideas and scientific approaches for model development, collected data, conducted data analysis and discussion, and bibliography. Gulnaz Hameed has supervised in data collection, model development, data estimation, review of the analysis results, and other technical aspects. Abdul Saboor was responsible for literature review, results translation, and review of the manuscript. Lal K. Almas was responsible for introduction write-up, general guidance, helped in model development, organized the whole manuscript and review of manuscript, conclusion \& policy recommendations, and incorporated the reviewers' suggestions.

Sources of Funding for Research Presented in a Scientific Article or Scientific Article Itself

The research in this manuscript has partially been supported by the Ogallala Aquifer
Program, a consortium of the USDA Agricultural Research Service, Kansas State University, Texas A \& M AgriLife Research, Texas A \& M AgriLife Extension Service, Texas Tech University, and West Texas A \& M University.

Visiting Research Fellow from Pakistan has been funded by Punjab Higher Education Commission (PHEC), Pakistan through his institution, PMAS- Arid Agriculture University, Rawalpindi, Pakistan.

Creative Commons Attribution License 4.0 (Attribution 4.0 International, CC BY 4.0)

This article is published under the terms of the Creative Commons Attribution License 4.0 https://creativecommons.org/licenses/by/4.0/dee d.en_US 